\title{
Yoruba Language
}

National Cancer Institute

\section{Source}

National Cancer Institute. Yoruba Language. NCI Thesaurus. Code C154204.

A Niger-Congo language spoken in West Africa. 